\title{
Participation in the Labour Market - Generation Y and Other Age Groups
}

Doi:10.5901/ajis.2014.v3n3p111

\section{Agnieszka Stanimir}

\author{
Wroclaw University of Economics \\ Email: agnieszka.stanimir@ue.wroc.pl
}

\begin{abstract}
The objective of the Europe 2020 strategy is to achieve the employment rate in 2020 on level of $75 \%$ for the European Union. Strategic objectives for the Member States are different. In Poland in 2020, the employment rate should reach $71 \%$. Employment rates differs depending on age groups, gender and country in which it is measured. There are also many factors that mobilizing generations to maintain employment. These factors determine the level of employment rate. They also cause that determination of the participation of social groups in the labour market is a multi-dimensional task. The aim of the study is to examine the labour market participation of people from generation $Y$ in comparisons to other age groups. People in this age group are guided by other values in lifestyle than older people. To achieve the objectives of the study were used statistical analysis methods adequate to the scale of measurement of factors observed on the labour market.
\end{abstract}

Keywords: generation Y, participation in labour market, Europe 2020 strategy, cluster analysis

\section{Introduction}

In June 2010 the European Council adopted the European Commission's proposal of Europe 2020 strategy. The creation of guidelines of this strategy was a response to effects of economic and financial crisis after 2007. The activities of the European Commission for the creation of the Europe 2020 strategy were based on the objective of achieving smart, sustainable and based on social inclusion growth. Social inclusion in accordance with the Communication from the European Commission Europe 2020 is understood as an activity for supporting the economy with high employment rate and social and territorial cohesion.

Implementation of the Strategy for 2010-2020 will promote achievement of the five main objectives in the following areas (European Commission, 2010):

1) Employment: employment rate of the 20-64 year-olds: $75 \%$ (for Poland $71 \%$ );

2) Research and development: $3 \%$ of the EU's GDP to be invested in R\&D (for Poland 1,7\%);

3) Climate change and energy sustainability: greenhouse gas emissions $20 \%$ (or even $30 \%$, if conditions are right) lower than 1990 (for Poland 14\%); $20 \%$ of energy from renewables (for Poland 15,48\%); $20 \%$ increase in energy efficiency (for Poland 14\%);

4) Education: reducing rates of early school leaving below 10\% (for Poland 4,5\%); at least 40\% of 30-34-yearolds completing third level education (for Poland 45\%);

5) Fighting poverty and social exclusion: at least 20 million fewer people in or at risk of poverty and social exclusion (for Poland 1,5 million).

The aim of the study is to examine the labour market participation of people belonging to the Generation $Y$ in comparisons to other age groups. So objectives of research were: evaluation of participation in the labour market of generation $Y$ and the older people; checking the level in 2013 of objectives of the Europe 2020 strategy in Poland compared to other countries of the European Union; comparison of the level of indicators of employment and unemployment in Poland and EU countries in 2013; analysis of percentage of population with tertiary level education as a factors determining the participation of young people in developing the labour market with high qualified workforce. Referred objectives of the article allow to assess one of the Europe 2020 Strategy flagship initiatives, i.e. inclusive growth (an agenda for new skills and jobs).

\section{Analysis of Employment Rate and Unemployment Rate}

Generation $Y$ is already participating in the labour market or is preparing to start work. They begin to play an important role in the workforce. Their outlooks upon life and work are reasons of many changes that need to introduce employer's managing young employees. There are also problems related to the meeting in one place of work of employees from 
different generations (Gen Y, Gen X, Baby Boomers). Managers must often solve the task of "how to turn this (Generation Y) high maintenance workforce into a high productivity workforce" (Martin, 2005). Unfortunately, even young people are confronted with a major problem in the labour market - unemployment. "The unemployment rate among them is getting higher in many European countries" (Generation $Y$ is entering the labour market, NKOS - Trnava, http://www.eza.org/en/publications/project-reports/structural-challenges-of-the-labour-market/generation-y-is-entering-thelabour-market-nkos-trnaval, retrieved 2014/04/27). In Fig. 1 are shown employment and unemployment rates of young Europeans.

Figure 1. Employment rates and unemployment rates of young Europeans

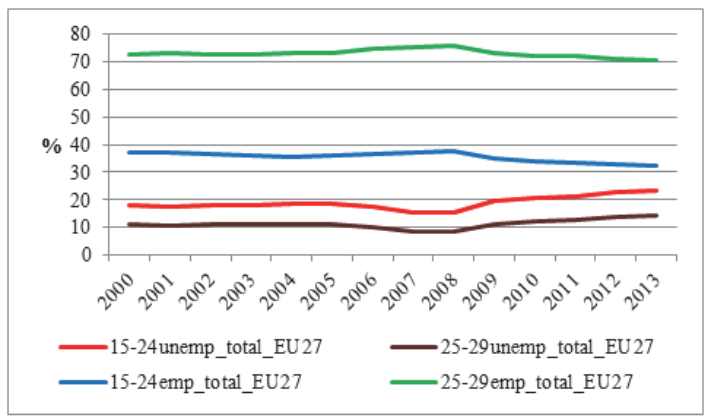

Source: Own elaborations on Eurostat data (Ifsa_urgan; Ifsa_ergan).

Employment and unemployment rates for both age groups were stable until 2006. During the years 2006 and 2007 the employment rate increased. However, in the following years the unemployment rate increased - ascending trend of this variable remained until 2013.

The unemployment rate and employment rate differs among gender. Therefore, in the analysis of these variables in 2013 included sex and age groups: younger and older. The division into age groups was made based on the available age groups in the EUROSTAT database.

The employment rate in EU countries in year 2013 is shown in fig. 2.

Figure 2. Employment rate of young and older Europeans in 2013

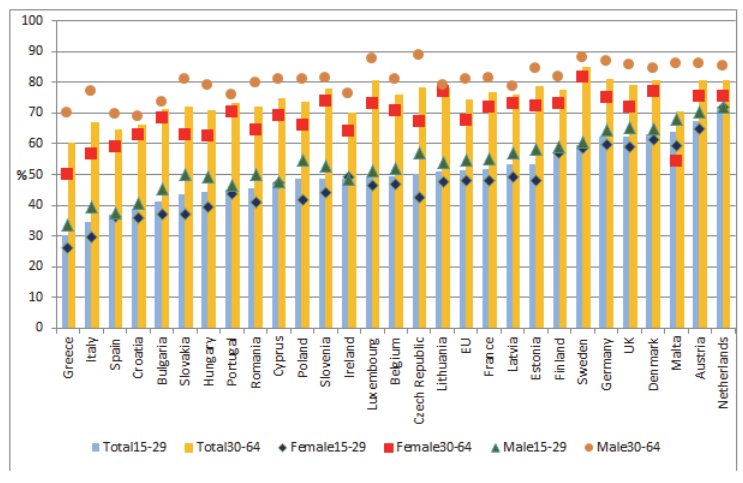

Source: Own elaborations on Eurostat data (Ifsa_ergan).

Highest differences between employment rate of younger and older citizens were in 2013 in Greece, Italy, Bulgaria, Slovenia, Luxembourg (nearly 30 percentage points the employment rate of young people was lower than the employment rate of older people). In countries with highest employment rate of younger people this differences were smaller. Employment rates for both men and women were much more smaller in younger group than in older (in each 
countries). Highest employment rates were observed for men in every country. In Poland all shown employment rates were average in comparison with other countries.

The unemployment rate in EU countries in year 2013 is shown in fig. 3.

Figure 3. Unemployment rate of young and older Europeans in 2013

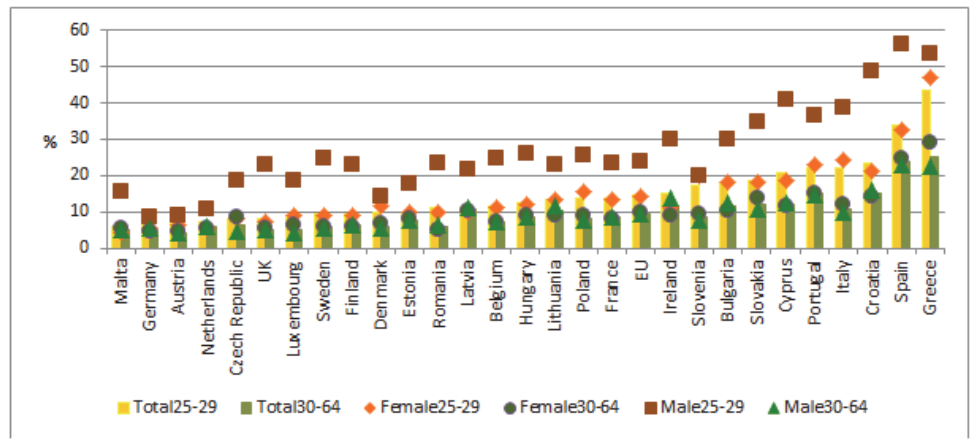

Source: Own elaborations on Eurostat data (Ifsa_urgan).

The lowest unemployment rate of younger citizens was observed in Malta, Germany, Austria. In this countries also unemployment rates of older people were really low. In Germany, Austria and Netherlands unemployment rates for older people in total, and for youngest and older men and women was lowest too. In Malta very high in comparison to other indices was unemployment rate of young men. Very high unemployment rates were observed in Spain and Greece. Situation on labour market in these countries of younger and older men and women was very difficult. In Poland the unemployment rate of older women and men was not high, but the level of this index observed for younger Poles was much higher.

\section{Analysis of percentage of population with tertiary education}

Fig. 4 shows percentage of both age groups with tertiary educational.

Figure 4. Population of young and older Europeans in 2013 with tertiary education

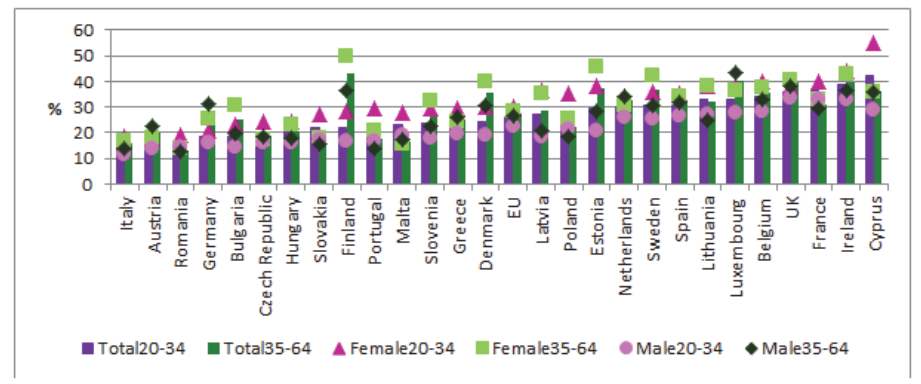

Source: Own elaborations on Eurostat data (edat_lfse_07).

However, on this basis, it cannot be stated that the young and older Europeans, who have a tertiary education have comparable knowledge. It is important for both younger and older people to attended in different kinds of lifelong learning.

According to the Europe 2020 strategy 40\% of EU citizens in age 30-40 should have a higher education by 2020 . The results of this procedure will be easier functioning of the labour market and increase job opportunities. In almost all countries the percentage of women (both age groups) with tertiary education was in 2013 higher than men. The 
percentage of young women with tertiary education was highest than for men and older women in Italy, Romania, Czech Republic, Hungary, Slovakia, Malta, Greece, Latvia, Poland, Belgium, France, Ireland, Cyprus (the highest of all). In Bulgaria, Finland, Slovenia, Denmark, Estonia, Sweden percent of older women with tertiary education was higher than younger women and all men. Only in Austria, Germany, Luxembourg percent of older men was higher than values of this index for all other analysed groups. In Poland percent of young and older women with tertiary education was in 2013 higher than for men.

\section{Cluster Analysis of Countries on the Basis of All the Variables}

The best way to find a similarly evaluated countries due to the considered variables are methods of classification. Dillon and Goldstein (1984) state that cluster analysis is a technique for data reduction, and that the goal of this methods is identify a smaller, homogenous groups of objects. For the analysis was chosen hierarchical classification by Ward. Adenberg (1973) underlines that Ward's method is based on within group variance.

Ward technique was performed to indicate the group of countries that have reached similar results in terms of inclusive growth. Fig. 5 presents a diagram for younger people, and fig. 6 for older. For younger people are distinguish eight classes, for older - seven.

Figure 5. Results of Ward classification - younger Europeans

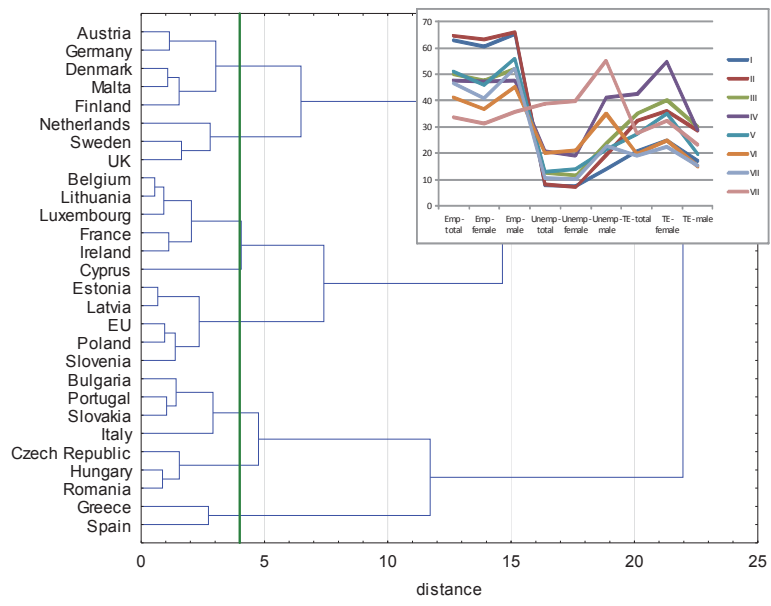

Source: Own elaborations on Eurostat data (Ifsa_ergan, Ifsa_urgan, edat_lfse_07).

Classes of countries for younger European are as follow (fig. 5):

I. Austria, Denmark, Finland, Germany, Malta;

II. Netherlands, Sweden, UK;

III. Belgium, France, Ireland, Lithuania, Luxembourg;

IV. Cyprus;

V. Estonia, Latvia, Poland, Slovenia;

VI. Bulgaria, Italy, Portugal, Slovakia;

VII. Czech Republic, Hungary, Romania;

VIII. Greece, Spain.

The highest level of employment rate in 2013 was observed in groups I and II (this implies a low level of unemployment rate in these two groups). In group I, the participation of people with higher education was among the lowest, while in group II was at an average level. In VIII group the highest unemployment rate was observed. In the countries belonging to this group both the employment rate as the percentage of men with higher education is very low. Poland participate in group of countries with average level of all variables in 2013. 
Figure 6. Results of Ward classification - older Europeans

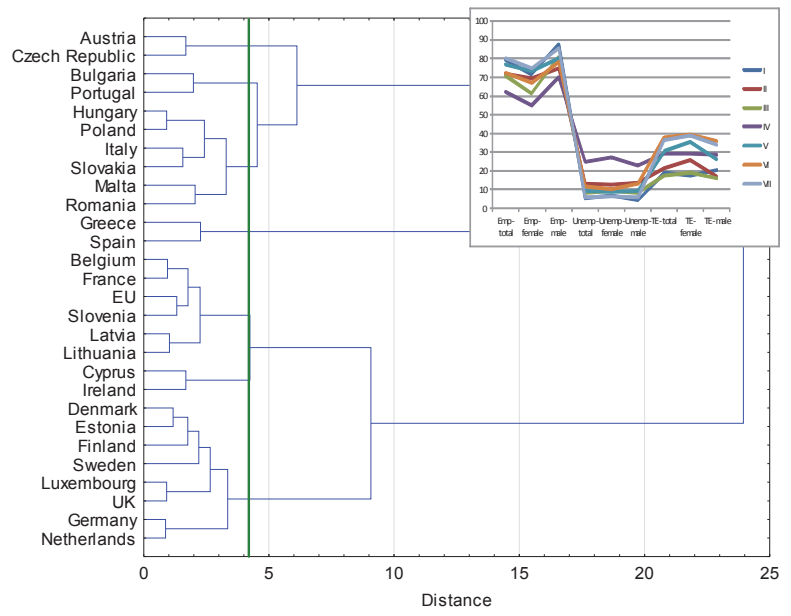

Source: Own elaborations on Eurostat data (Ifsa_ergan, Ifsa_urgan, edat_Ifse_07).

Classes of countries for older European are as follow (fig. 6):

I. Austria, Czech Republic;

II. Bulgaria, Portugal;

III. Hungary, Italy, Malta, Poland, Romania, Slovakia;

IV. Greece, Spain;

V. Belgium, France, Latvia, Lithuania, Slovenia;

VI. Cyprus; Ireland;

VII. Denmark, Estonia, Finland, Germany, Netherland, Luxembourg, UK.

Group VII contains countries in which the highest level of employment, the lowest unemployment rate and the highest the participation of people with higher education were observed. This group includes countries which in classification of young Europeans were among the best two groups. In the group number IV are countries where indicators were rated the same as for younger Europeans. They are Greece and Spain. Poland is in group number III in which are countries where employment rate of women was one of the lower and of men in 2013 was high. In this group unemployment rate of men and women was low. In group number III percentage of older people with tertiary education was in 2013 one of lower in this age group among all countries.

\section{Conclusions}

Results of the analysis indicated that employment rates calculated for age groups significantly differ from each other. Highest values of this rate was in 2013 for people aged over 30 years. The lowest value was for people aged 19-24 years. Accomplishment of a fixed value for the year 2020 the number of employment rate at the level of $75 \%$ for the whole European Union will require significant efforts in all Member Countries. Among countries of the EU-28, there are significant differences in the level of employment rates in 2013: 30\% for young Greeks (60\% - older Greeks) to $72 \%$ for young Dutch (85\% of older Swedes). The level of unemployment rate corresponds to the rate of employment. Here among young people the highest unemployment rate was observed in Greece $-43.5 \%$ and the lowest in Malta $-6 \%$. Among older people, the unemployment rate fluctuated between 4\% (Austria) and 25\% (Greece). Among all countries of the EU can be indicated countries in which analyzed indicators take a similar level. For example, both young and older citizens of Greece and Spain have been classified into one group - the worst group in terms of employment and unemployment rate. Older Polish people also have been included in one of worse groups with regard employment rate but this class has a very high level of the percentage of people with higher education. 


\section{Acknowledgements}

This study was done as a part of the project "Non-metric multivariate data analysis as a tool for study of adults situation in the context of demographic changes" financed by Narodowe Centrum Nauki (National Science Centre) in Poland. Project number: 2012/05/B/HS4/02499.

\section{References}

Adenberg, M. R. (1973). Cluster Analysis for Applications. London: Academic Press.

Dillon, W. R., \& Goldstein, M. (1984). Multivariate Analysis. Methods and Applications. Singapore: Hohn Wiley \& Sons.

European Commission. (2010). Communication from the Commission - Europe 2020. A strategy for smart, sustainable and inclusive growth. European Commission, COM(2010) 2020 final.

Generation Y is entering the labour market, NKOS - Trnava, http://www.eza.org/en/publications/project-reports/structural-challenges-ofthe-labour-market/generation-y-is-entering-the-labour-market-nkos-trnaval, retrieved 2014/04/27.

Martin, C. A. $(2005,37)$. From high maintenance to high productivity. What managers need to know about Generation Y. Industrial And Commercial Training , strony 39-44. 